\title{
13.P11
}

\section{Acquisition of the Immunophenotype by Human Adrenal Cells}

\author{
Vincenzo Silani, Donatella Mariani, Maria Franca Donato, *Mauro Buscaglia, *Giorgio Pardi and \\ Guglielmo Scarlato
"Dino Ferrari" Center - Institutes of Neurology and * Obstetrics and Gynecology of the University of Milan Medical School, Via F. Sforza 35, I-20122 Milan, Italy

The use of adrenal medullary autografts as a treatment for Parkinson's disease stimulated a renewed interest in the neurobiology of the adrenal gland. Much of what is known concerning the human fetal adrenal medulla comes from the report of Hervonen /1/. During embryogenesis, the neural crest serves as a pool of precursor cells, which migrate to specific locations, the environment contributing in a decisive manner to the determination of the final cell fate. Human chromaffin cells from the neural crest migrate to reach the ultimate location in the adrenocortical anlagen after 9 weeks of gestational age. The endocrine cell phenotype is subsequently determined by cell migration and by cell response to specific trophic factors and hormones (steroids).

This study examines the acquisition of immunophenotype by ganglion and chromaffin cells (Chr). The neural crest consists of pluripotent cells that migrate to reach the adrenocortical anlagen after 9 weeks of gestation in humans. Sections were examined from adrenals at the 9 th to 20 th weeks of gestation. Primary antisera against neuron specific enolase (NSE), neurofilament subunits (NF), chromogranin (ChrA), tyrosine hydroxylase (TH), dopa decarboxylase (DDC), dopamine $\beta$-hydroxylase (DBH), phenyl-ethanolamine-N-methyl-transferase (PNMT), and NGF receptor-low affinity protein (mouse clones ME20-4 and 8211) were used. The following cell subpopulations were demonstrated in the fetal adrenal sections: 1) scattered and isolated $>$ clustered $\mathrm{NSE}^{+}, \mathrm{NF}^{+/-}$, $\mathrm{ChrA}^{-}, \mathrm{TH}^{+}, \mathrm{DDC}^{-}, \mathrm{DBH}^{-}, \mathrm{PNMT}^{-}$ganglion cells; 2) scattered and isolated or clustered $\mathrm{NSE}^{+}, \mathrm{NF}^{+/}, \mathrm{ChrA}^{+}, \mathrm{TH}^{+}, \mathrm{DDC}^{+}, \mathrm{DBH}^{+}$, few $\mathrm{PNMT}^{+}$chromaffin cells; and 3 ) NSE; $\mathrm{NF}^{-}$,
ChrA', $\mathrm{TH}^{-}, \mathrm{DDC}^{-}, \mathrm{DBH}^{-}, \mathrm{PNMT}^{-}$adrenocortical cells. Adrenal primary cultures were obtained as previously described. Adrenal cells in culture showed: 1) $\mathrm{NSE}^{+}, \mathrm{NF}^{+}, \mathrm{ChrA}^{+/}, \mathrm{TH}^{+}$, $\mathrm{DDC}^{+/}, \mathrm{DBH}^{+/}$, few $\mathrm{PNMT}^{+/-}$ganglion and $\mathrm{Chr}$; 2) ganglion/Chr purification and survival also without NGF; 3) NGF receptor expression on $\mathrm{TH}^{+}$and "sustentacular" TH-cells; 4) NGFinduced neurite outgrowth. $\mathrm{TH}^{+}$ganglion and $\mathrm{Chr}$ represent distinct cell populations at a very early stage of embryogenesis both in vivo and in vitro (Table).

The influence of NGF on adrenal cell development was further characterized: the whole NGF molecule (7S NGF) and the active subunit (2.5S NGF) were assayed in primary cultures. Cells respond to 7S NGF with prompt neurite elongation, inhibition of sustentacular cell proliferation, and increase in time of survival. The 2.5S NGF effect was comparable. A biological titration curve with decreasing concentrations of 7S NGF (from $100 \mathrm{ng} / \mathrm{ml}$ to $0.1 \mathrm{ng} / \mathrm{ml}$ ) was drawn demonstrating the presence of a biological effect even at the minimal concentration.

Adrenal neurotransplantation, aside from the clinical impact on the treatment in Parkinson's disease, is responsible for renewed efforts to clarify the complex neurobiology of the neural crest derivatives. The adrenal gland remains a putative dopaminergic donor in Parkinson's disease and the usefulness of the fetal adrenal has not been completely explored. Our first goal was to identify the different cell subpopulations from early gestational ages so as to define better the optimal cell donor (dopamine-producer). These studies resulted in the identification of two major distinct $\mathrm{TH}^{+}$cell derivatives during early development: chromaffin cells and ganglionic 
TABLE - MAJOR ADRENAL CELL IMMUNOPHENOTYPE BOTH IN VIVO and IN VITRO

\section{GANGLION CELLS}

scattered and isolated $>$ clustered $\mathrm{NSE}^{+}, \mathrm{NF}^{+/-}, \mathrm{ChrA}^{-}, \mathrm{TH}^{+}, \mathrm{DDC}^{-}, \mathrm{DBH}^{-}, \mathrm{PNMT}^{-}$cells

\section{CHROMAFFIN CELLS}

scattered and isolated/clustered $\mathrm{NSE}^{+}, \mathrm{NF}^{+/-}, \mathrm{ChrA}^{+}, \mathrm{TH}^{+}, \mathrm{DDC}^{+}, \mathrm{DBH}^{+}$, few $\mathrm{PNMT}^{+}$cells

\section{ADRENOCORTICAL CELLS}

$\mathrm{NSE}^{-}, \mathrm{NF}^{-}, \mathrm{ChrA}^{-}, \mathrm{TH}^{-}, \mathrm{DDC}^{-}, \mathrm{DBH}^{-}, \mathrm{PNMT}^{-}$cells

cells, with two different final destinies. Tissue culture significantly contributed to our comprehension of basic mechanisms and trophic influences regulating their cell interactions and differentiation. Both types of $\mathrm{TH}+$ cells (ganglion and $\mathrm{Chr}$ ) can be separately considered for intracerebral graft and successfully cryopreserved $/ 3 /$. Chr being neuronal crest derivatives, the expected neurotrophic factor at play is NGF; in fact, NGF-R was co-localized with chromaffin cell clusters. The in vitro experiments complemented the NGF data showing its effects on cell survival and differentiation.

Information obtained on the human gland development represents a useful neurobiological basis for the design of innovative strategies for grafting in Parkinson's disease.

\section{REFERENCES}

1. Hervonen A. Development of catecholamine storing cells in human fetal paraganglia and adrenal medulla. Acta Physiol Scand 1971 Suppl 368.

2. Silani V, Pezzoli G, Motti E, Ferrante C, Falini A, Pizzuti A, Zecchinelli A, Moggio M, Buscaglia M, Scarlato G. Characterization of purified populations of human fetal chromaffin cells: considerations for grafting in parkinsonian patients. Prog Brain Res 1988; 78: 551-557.

3. Silani V, Pizzuti A, Strada O, Falini A, Pezzoli G, Scarlato G. Cryopreservation of human fetal adrenal medullary cells. brain Res $1988 ; 454: 383-386$. 

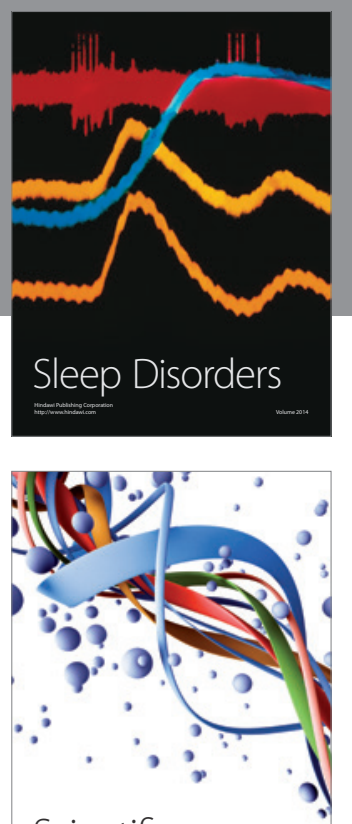

Scientifica
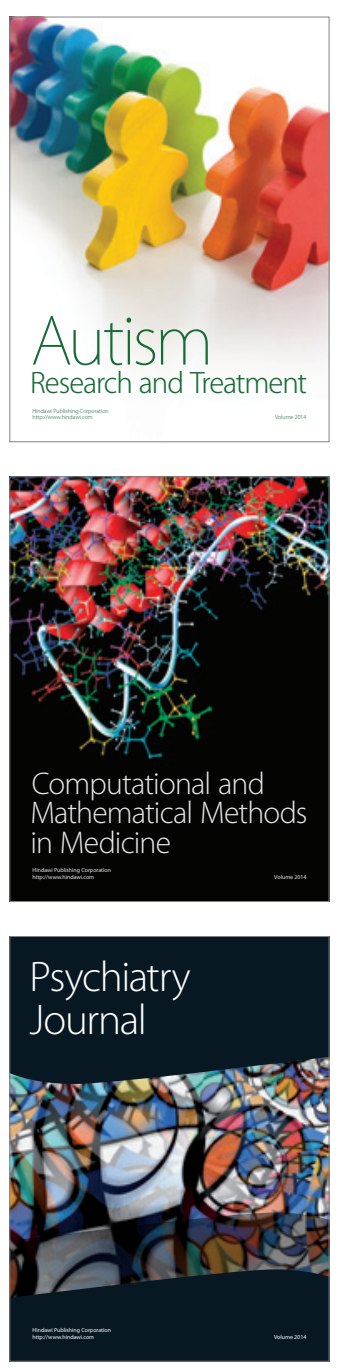
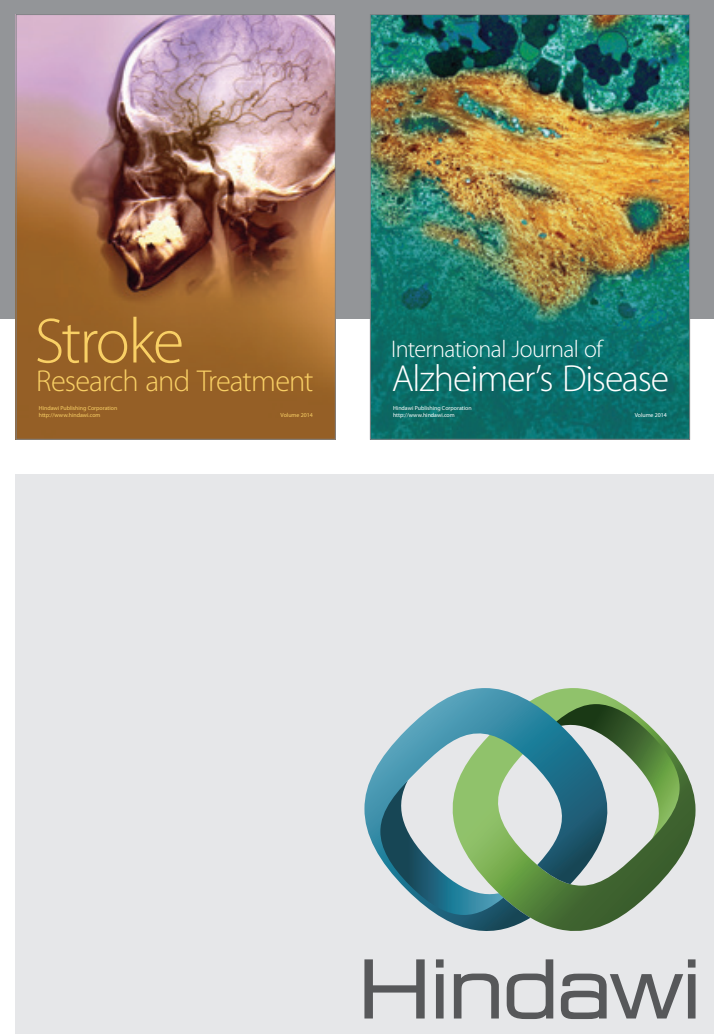

Submit your manuscripts at

http://www.hindawi.com
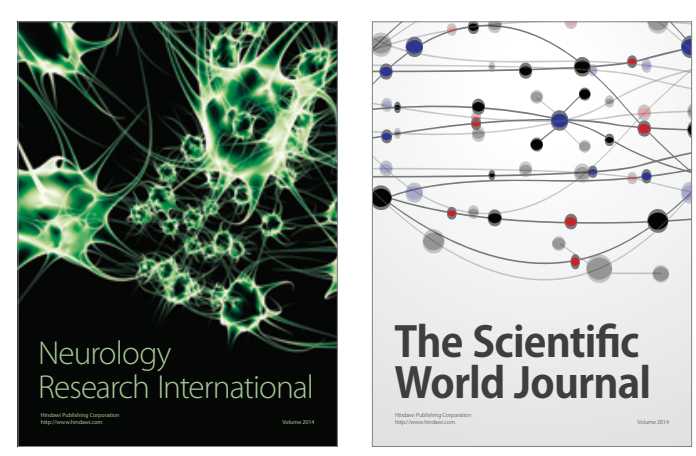

The Scientific World Journal

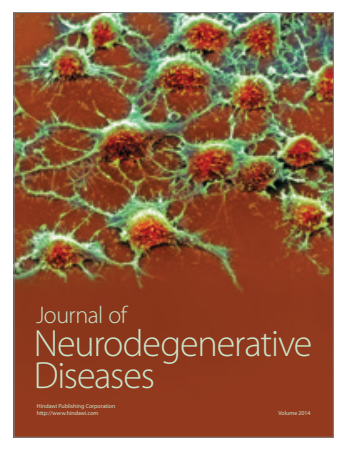

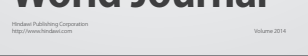

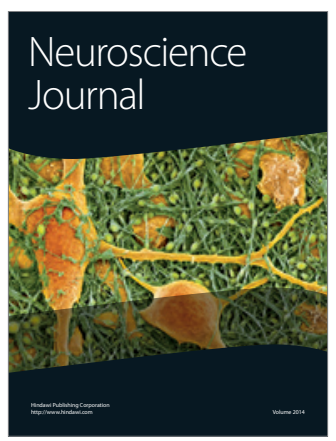

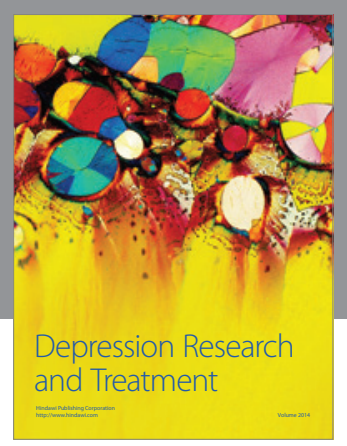
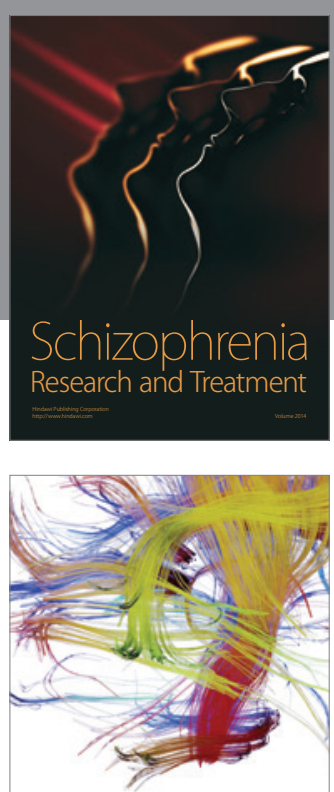

Brain Science

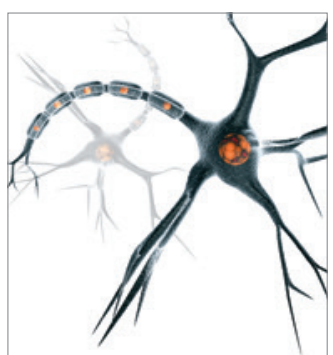

Neural Plasticity
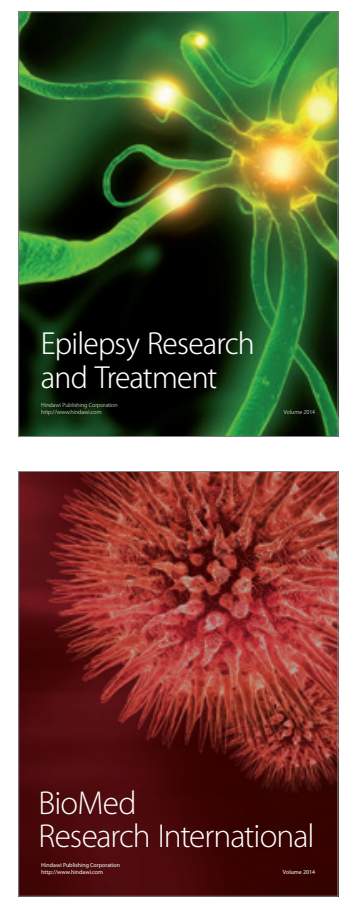

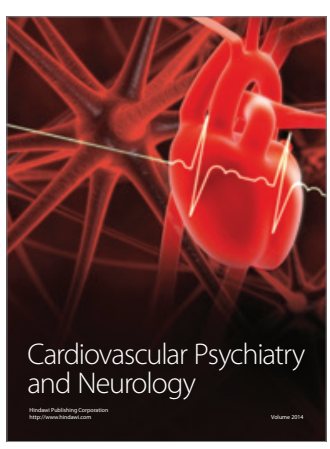

Parkinson's

Disease
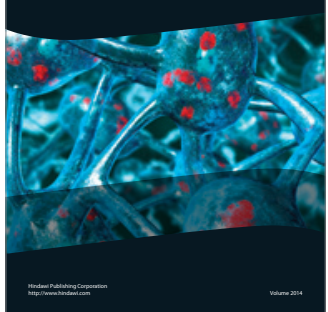